\title{
内装用建材の複素比誘電率とその変動に関する検討 A STUDY ON THE COMPLEX RELATIVE PERMITTIVITY AND ITS VARIATION FOR INTERIOR BUILDING MATERIALS
}

\author{
木 村 健 一*, 新 納 敏 文**, 橋本 修*** \\ Ken-ichi KIMURA, Toshifumi SHINNOH and Osamu HASHIMOTO
}

\begin{abstract}
Complex relative permittivity, which is one of the important electrical constants of materials for electromagnetic compatibility inside and/or around building, is estimated by iteration calculation using four measurements of the magnitude of reflection coefficient from Free Space Measurement System. The estimation conducts for $1.55 \mathrm{GHz}$ to $6.5 \mathrm{GHz}$ frequency range including wireless LAN frequency, and the complex relative permittivity of the 9 kinds of interior building materials, including plaster boards and fiber reinforced cement boards are presented. The results of the work have good agreement to the previous works. The variation for frequency and samples of the complex relative permittivity also conduct for these samples.
\end{abstract}

Keywords : Complex Relative Permittivity, Building Material, Fiber Reinforced Cement Board, Water Content 複素比誘電率，建材，繊維強化セメント板，含水率

\section{1、はじめに}

近年, 情報化社会の進展によって多くの無線技術が実際に使われ るようになってきている。建物の内外をとっても室内無線やビル間 無線など身近な技術となってきているのが現状である。特に IEEE802.11 各タスクグループによる無線 LAN の規格統一を機に多 くの無線 LAN 機器が建物内部を中心に使用されるようになり,建物 内での電波伝播が重要な課題として議論されつつある。そのために は建物を構成する建築部材の比誘電率, 比透磁率などの電気定数を 正確に把握する必要がある。

建物を構成する材料は鉄骨や鉄筋などの金属を除けば，多くはセ メントや珪酸などを主成分とした宰業系の材料で構成されており， それらはすべて誘電体である。電波伝播など電磁問題を議論する場 合には，比誘電率の損失成分を含めた複素比誘電率を扱う必要があ る。複素比誘電率の測定については，既に多くの研究がなされてお り, 導波管法, 共振器法や自由空閒法などが提案されている 建材の誘電率の測定に限っても, 多くの研究が TV 周波数帯域で なされており 2),3),4),5)，最近では $\mathrm{GHz}$ 帯域まで検討した(例 (2),7),8),9)もあ る。しかしながら，それらはコンクリートやモルタルなどの材料に 関する検討が主であり，内装用の建材を扱ったものは極めて少ない のが現状である。さらにそれらの検討の多くは単一周波数に関する
ものであったり, 限られた材料に関するものであったりして, 複素 比誘電率の変動に関して研究されたものは極めて少ない。

このような背景のもと，筆者らは建物の内部に焦点を絞り，マイ ク口波を中心とした帯域における無線通信を快適に行うための電磁 環境の構築を目指して研究開発を行ってきた ${ }^{10)}$ 。本論文ではそのた めの基䃈的な検討として, 内装用建材の複素比誘電率とその周波数 や材料間の変動・ばらつきについて検討した。

自由空間法による複素比誘電率の算出では，レンズアンテナを使 った透過法 ${ }^{(1), 12)}$ や反射法との組み合わせ ${ }^{13)}$ などが提案されているが, 本研究では, 比較的測定が容易な自由空間反射損失法によって材料 の 4 つの状態での反射係数の振幅值を測定し，その測定值と推定し た複素比誘電率から計算した值との差を最小にする方法で推定した。

まず, 自由空間反射損失法の測定系と複素比誘電率の算出方法を 述べ，次に代表的な内装用建材である 9 種類の材料の複素比誘電率 について周波数分布を，無線 LAN 使用周波数帯域を含む $1.55 \mathrm{GHz}$ $\sim 6.5 \mathrm{GHz}$ 帯域で算出した。さらに 3 種類の材料について周波数ごと の変動と材料間の標準偏差を求め, 同一バッチで製造された材料の 複素比誘電率のばらつきを評価した。また, 同一試料で測定の配置 を変化させ，試料内のばらつきも評価した。最後に本手法で用いた 計算の収束值と複素比誘電率の偏差との関係を検討した。

\footnotetext{
* 侏フジタ技術センター 主任研究員・工博

**(侏)フジ技術センター 部長・工博

*** 青山学院大学理工学部 教授·工博

Researcher, Technology Development Division, Fujita Corporation, Dr. Eng. General Manager, Technology Development Division, Fujita Corporation, Dr. Eng. Prof., Dept. of College of Science and Engineering, Aoyama Gakuin University, Dr. Eng.
} 


\section{2. 反射係数の測定及び複素比誘電率算出方法}

Fig.1 に材料の反射係数の測定システムを示す ${ }^{14)}$ 。本測定系では, 電波を下方から上方に向け放射し, 測定試料を床から $1.2 \mathrm{~m}$ の位置 に配置して測定を行う。試料は発泡スチロールのみによって保持さ れているので試料近傍に反射波を生ずる材料はなく，試料近傍から の不要な反射波を抑えることが可能である。さらに試料上部にピラ ミッド型吸収体を配置し, 室内の壁や天井などからの不要反射波を 抑制している。測定系に設置した送受信アンテナはネットワークア ナライザーにつながっており, Fig.1 の測定システムでは, アンテナ の特性により $1 \mathrm{GHz} \sim 18 \mathrm{GHz}$ までの測定が可能である。

反射係数の測定は, 試料と同一寸法の金属板（アルミ板, 厚さ

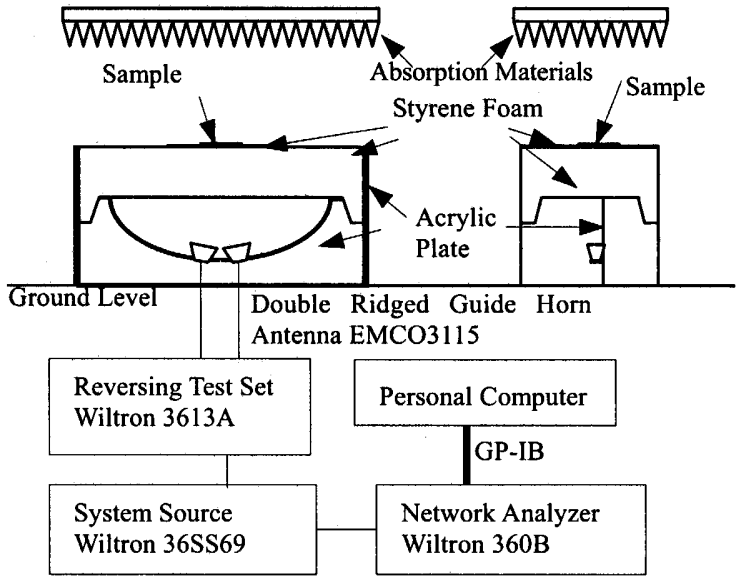

Fig. 1 Outline of the measurement system

$1.5 \mathrm{~mm}$ ）を完全反射体とし，それを基準にして行った。すなわち， 金属板を置いた際の反射係数の周波数スペクトルとまったく同じ状 態で測定試料を設置した際に得られるスペクトルの比を各周波数に おける反射係数とした。本測定システムで測定可能な反射係数の最 大振幅值は，1GHz〜 $13.5 \mathrm{GHz}$ において $50 \mathrm{~dB}$ である。

本測定システムの有効性については，既にアクリル板を使った 検討 ${ }^{14)}$ がなされているが，その一例として寸法 $300 \mathrm{~mm}$ 角のアクリ ル板（厚さ $5 \mathrm{~mm}, 7 \mathrm{~mm}, 10 \mathrm{~mm}$ ）の反射係数測定から得られる振幅

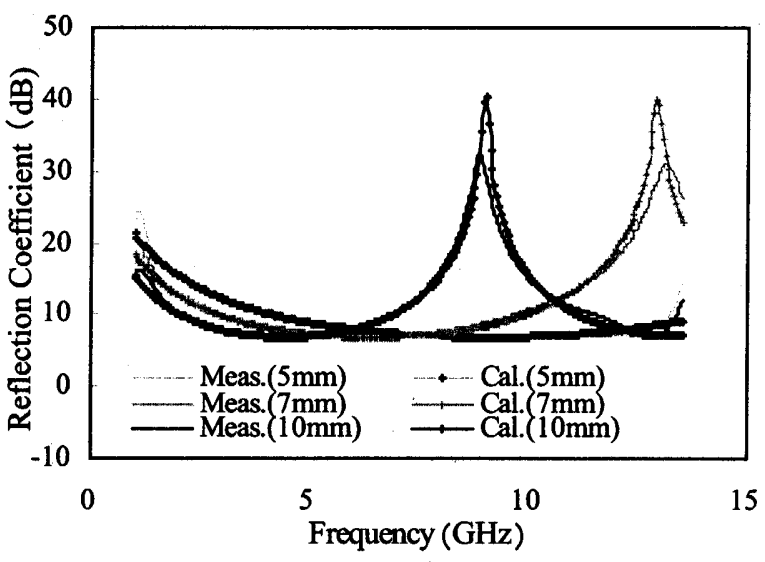

Fig.2 Comparison on the reflection coefficient between measurement and calculation for acrylic plate
値と文献 ${ }^{15}$ に示された複素比誘電率から式(1)〜 (5)で算出した計算 值とを Fig.2に示す。

$$
\begin{aligned}
& \dot{Z} \text { te }^{\mathrm{o}}=\dot{\mathrm{Z}} \mathrm{cte} \cdot \frac{Z_{0} / \cos \theta^{+} \dot{Z} \mathrm{cte} \cdot \tanh (\dot{\gamma} d)}{\dot{Z}_{\mathrm{cte}+} \mathrm{Z}_{0} / \cos \theta^{\cdot \tanh (\dot{\gamma} d)}} \\
& \dot{Z} \text { cte }=\frac{Z_{0}}{\sqrt{\dot{\varepsilon}_{r}-\sin ^{2} \theta}} \\
& \dot{\gamma}=j \frac{2 \pi}{\lambda} \sqrt{\dot{\varepsilon}_{r}-\sin ^{2} \theta} \\
& \dot{\Gamma} \mathrm{o}=\frac{\dot{\mathrm{Z}} \mathrm{te}^{\mathrm{o}}-Z_{0} / \cos \theta}{\dot{\mathrm{Z}} \mathrm{te}^{\mathrm{o}}+Z_{0} / \cos \theta} \\
& =|\dot{\Gamma} \mathrm{o}| \cdot \exp (\mathrm{j} \cdot \phi)
\end{aligned}
$$

ここでŻ $\mathrm{te}^{\mathrm{o}}, \dot{\Gamma} \mathrm{o}$ は試料の背面に金属板を配しない試料のみの TE 波 に対する入カインピーダンス及び反射係数（以下この測定をオープ ン(Open)測定と称す)，Żcte， $\mathrm{Z}_{0}$ は $\mathrm{TE}$ 波に対する材料の特性インピ 一ダンス及び空気の特性インピーダンス, $\dot{\varepsilon}_{r}, d$ は試料の複素比誘 電率及び厚さ， $\theta$ は入射角度, $|\dot{\Gamma} 0|$ は反射係数の振幅を， $\phi$ は位相 を示している。

なお、本論文では以下の測定も含めて，用いた試料の寸法は $300 \mathrm{~mm}$ 角，測定周波数は $1 \mathrm{GHz} \sim 13.5 \mathrm{GHz}$ で測定点 501 点 $(25 \mathrm{MHz}$ ステップ)，TE 偏波で入射角度は 8.5 度とした。これらの测定条件 は，以前の検討 ${ }^{14)}$ でその有効性を確認してある。特に試料寸法につ いては, $300 \mathrm{~mm}$ 角で有意な測定結果が得られることを確認している。 そして, 測定後タイムドメインでのグーティング処理 ${ }^{16)} に よ り$ 不要 反射波を除去した。

Fig.2 に示されているように反射倸数の振幅值において計算值と 測定值は，ゲーティング処理によって生じたひずみの影響がでてい る測定周波数両端を除きよく一致していることが確認できる。

以上のことから，本測定系による反射係数の振幅值は精度よい測 定が可能である事がわかった。一方，自由空間法においては位相の 測定は振幅值の測定に比べて精度の劣ることが知られている。その ため、複素比誘電率の算出には振幅值のみを用いたほうが精度の高 い評価が期待できる。しかし式(1)〜式(5)は複素成分を含んでいるた め, 試料単体での 1 つの振幅値のみからでは解析的に解くことはで きず, 単一の解を得ることはできない。そこで, 試料の状態を変化 させ複数の振幅值を得れば, 数值計算を使って複素比誘電率を算出 することが可能になる。

試料の状態を変化させる方法としては, 試料の厚さを変化させる ことや，入射前面や董面に既知の材料を挿入する方法，そして裏面 に金属を配置する方法などが考えられる。例えば，大塚ら”は試料 の厚さと入射角度を変化させ低損失材料の複素比誘電率を測定して いる。しかしながら，本論文で対象としているのは一般建材である ことから，異なる試料厚の同一試料を得ることは困難であるため試 料の厚さを変化させた測定は困難である。また, 試料の入射前面や 裏面に既知の材料を挿入する方法は，入手可能な既知材料は低損失 材料であるため，有意な測定を行うためには挿入する材料の厚さが 大きくなり，測定試料の全体厚が大きくなってしまうといった問題 点がある。そのため，本論文では裏面に金属を配置することにより 
試料の状態を変化させた測定を行うこととした。

さらに，入射する面を変えることによって合わせて 4 つの测定值 が得られ，その振幅值から数値計算によって試料全体としての複素 比誘電率を精度よく求めることが期待される。これは, 建材のよう な非均一で試料内の場所によるばらつきの大きい材料の場合には, 材料全体の複素比誘電率を評価する上で有効な方法であると考えら れる。複素比誘電率などの材料測定の際, その対象試料は均一なも のを扱う場合が多いが，本論文で扱っているような不均一な材料の 場合，金属板の有無による反射係数振幅值の 2 つのデータのみでは 十分に収束しない可能性がある。また，これらの材料の表裏は便宜 的な場合も多く，実際に使われる際にはその表裏の区別がないこと も珍しくない。したがって，このような材料の場合，試料全体とし ての複素比誘電率は, 試料の表裏それぞれのオープン及びショート 測定による計 4 つの反射係数の振幅値からの評価が有効である。

試料の背面に金属板を配した測定（以下ショート(Short)測定と称 す）から得られる反射係数の振幅値は以下の式であらわされる。

$$
\begin{aligned}
\dot{Z} \mathrm{te}^{\mathrm{s}} & =\dot{\mathrm{Z}} \mathrm{cte} \cdot \tanh (\dot{\gamma} d) \\
\dot{\Gamma}_{\mathrm{s}} & =\frac{\dot{\mathrm{Z}} \mathrm{te}^{\mathrm{s}}-Z_{0} / \cos \theta}{\dot{\mathrm{Z}} \mathrm{te}^{\mathrm{s}}+Z_{0} / \cos \theta} \\
& =|\dot{\Gamma} \mathrm{s}| \cdot \exp (\mathrm{j} \cdot \phi)
\end{aligned}
$$

ここで, $\dot{Z} \mathrm{te}, \dot{\Gamma}_{\mathrm{s}}$ は試料の背面に金属板を配した TE 波に対する入力 インピーダンス及び反射係数で, $|\dot{\Gamma} \mathrm{s}|$ は振幅である。

すなわち周波数 $f$ において，表面から入射しオ一プン測定，裏面 から入射しオープン測定, 表面から入射しショート測定, 裏面から 入射しショート測定の振幅值をそれぞれ $|\dot{\Gamma} \mathrm{of}|_{m}^{\prime},|\dot{\Gamma} \mathrm{ob}|_{m}^{\prime},|\dot{\Gamma} \mathrm{sf}|_{m}^{\prime}, \mid \dot{\Gamma} \mathrm{s} \mathrm{b}_{m}^{\prime}$ と する。一方, 初期複素比誘電率 $\dot{\varepsilon}_{r \text { ini }}(f)$ から式(1) (8)によりオープ

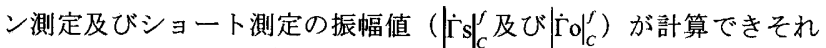
らから式(9)の差分値 $\Delta|\dot{\Gamma}|$ が得られる。この差分値を最小にするよう な反復計算によって複素比誘電率 $\dot{\varepsilon}_{r}(f)$ を求めることができる。

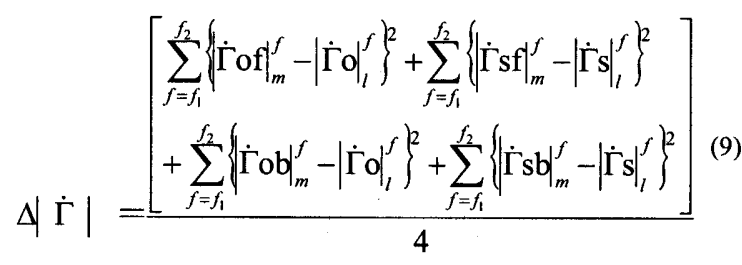

$$
\dot{\varepsilon}_{r}(f)=\varepsilon_{r}(f)^{\prime}-j \varepsilon_{r}(f)^{\prime \prime}
$$

ここで, 建材などの誘電体はその含水率が $20 \%$ 以下の場合, 周波 数帯域 $1 \mathrm{GHz} \sim 10 \mathrm{GHz}$ では複素比誘電率の変動幅は微小であること が報告されている ${ }^{6,8)}$ 。そこで式(9)の差分值を計算する際に式(10) で規定した複素比誘電率の周波数に対する標準偏差をとり, その值 が一定值（以下偏差上限值と称す）を超えないとの仮定の元で反復 計算を行い、差分值 $\Delta|\dot{\Gamma}|$ が最小となる際（収束点）の $\dot{\varepsilon}_{r}(f)$ を求め る複素比誘電率とする。

以上の計算式を元に本論文では内装用建材の複素比誘電率を求め その変動を検討するが, 複素比誘電率算出の際の対象周波数帯域は $1.55 \mathrm{GHz} \sim 6.5 \mathrm{GHz}, 100$ 点 $50 \mathrm{MHz}$ ステップで，偏差上限值は Rhim らのモルタルの複素比誘電率測定 ${ }^{8)}$ における周波数変動の最大值か

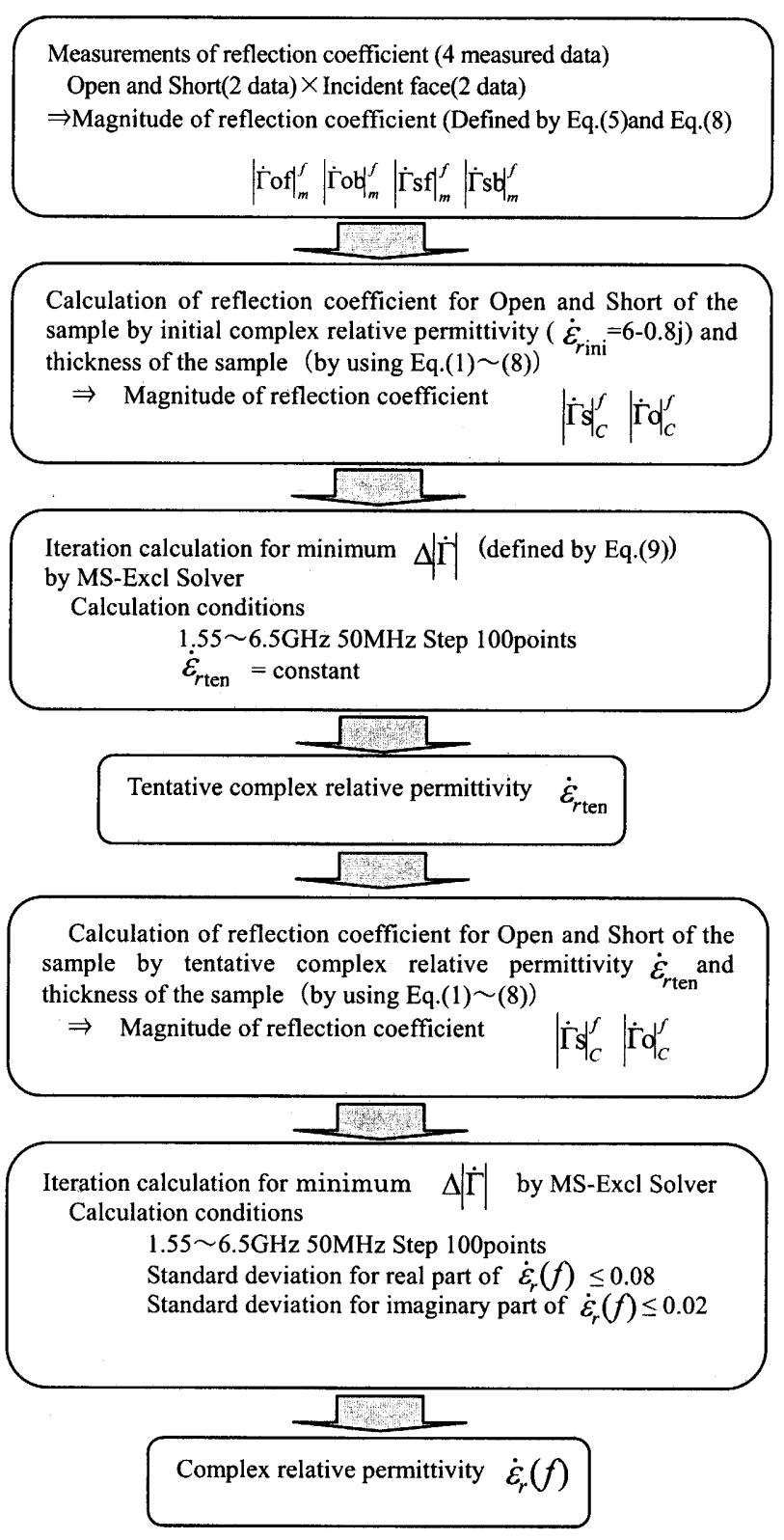

Fig.3 Calculation algorithm for the complex relative permittivity

ら実部で 0.08 、虚部で 0.02 とした。また, 初期值複素比誘電率 $\dot{\varepsilon}_{\text {rini }}$ は, 周波数によらずコンクリート系材料の一般値である $6-0.8 \mathrm{j}$ で一定と した。

実際の複素比誘電率の算出は, 以下の 2 段階で行った。まず, 測 定によって得られた 4 つの振幅値と初期複素誘電率 $\dot{\varepsilon}_{\text {rini }}(6-0.8 \mathrm{j})$ 及 び試料の厚さから, 式(10)の複素比誘電率が一定との条件下で, 式 (9)の差分值 $\Delta|\dot{\Gamma}|$ が最小となるような暫定複素比誘電率 $\dot{\varepsilon}_{\text {rten }}$ MS-Excel のソルバーを使って導出する。次に $\dot{\varepsilon}_{\text {rten }}$ と測定值から， 各周波数での複素比誘電率の標準偏差が 0.08 (実部), 0.02(虚部)以下 であるとの条件下で, 式(9)の差分値 $\Delta|\dot{\Gamma}|$ が最小となる複素比誘電率 $\dot{\varepsilon}_{r}(f)$ を MS-Excel のソルバーを使って計算する。この 2 段階の計 算方法により, 求める複素比誘電率が, 初期値 $(6.0-0.8 \mathrm{j})$ と大き 
く異なっていても, 暫定複素比誘電率の算出を経て, 再現よく複素 比誘電率が算出できる。Fig.3に本論文で用いた複素比誘電率の算出 のアルゴリズムをフロー図で示す。

\section{3. 内装用建材の複素比誘電率}

前項で述べた計算方法に従って内装用建材の複素比誘電率の周波 数特性を求めた。測定に供した試料は, 葖業系の材料として繊維強 化セメント板 (4 種類 14 枚)，石膏ボード (2 種類 6 枚), 岩綿吸音 板 (1 種類)，そして木材（2 種類 2 枚）で，寸法が $300 \mathrm{~mm}$ 角で一

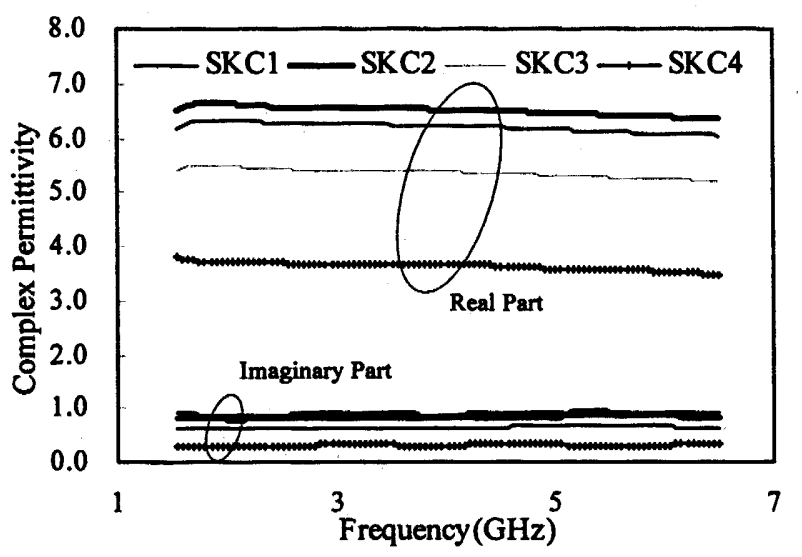

Fig.4 Frequency distribution curve of complex relative permittivity for fiber reinforced cement board

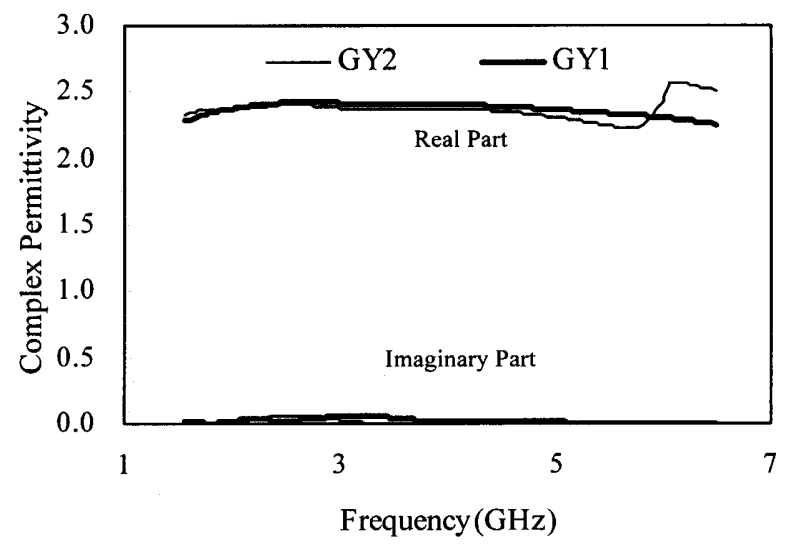

Fig.5 Frequency distribution curve of complex relative permittivity for plaster board

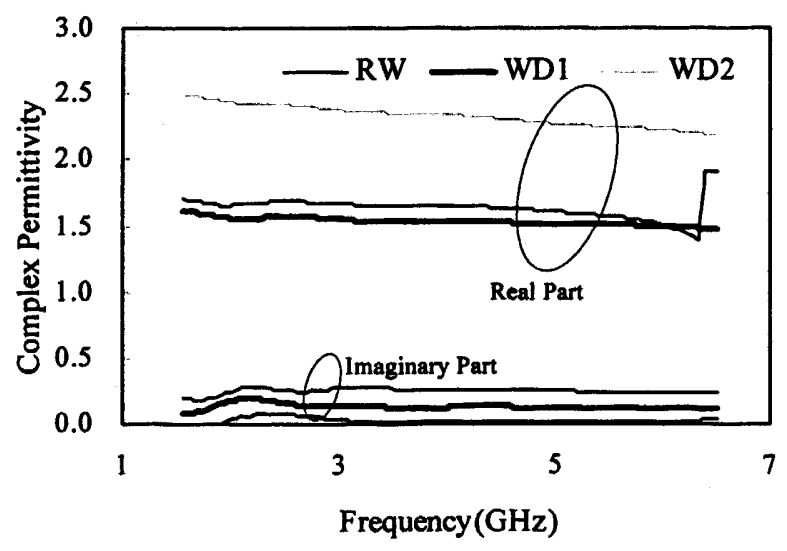

Fig.6 Frequency distribution curve of complex relative permittivity for sound absorbing board and wood
部を除き市販されている材料を用い, 複数枚のものは同じバッチの ものを入手した。Table1 に測定した材料の一覧と測定時の比重及び 厚さを示寸 (複数枚あるものはそれぞれの平均値を記してある)。こ れらの試料は恒温養生室（温度 $20^{\circ} \mathrm{C}$, 相対湿度 $60 \%$ ）で一定期間養 生し試料内の含水率が均一になるようにした後, 測定を行った（こ れらの空業系の材料は製造直後に蒸気養生などの特殊な処理をして いるため，コンクリートなどに見られるような材料の経年変化は少 なく，そのため本論文においてその影響は考虑していない)。

Fig.4 に繊維強化セメント板, Fig.5 に石膏ボード, そして Fig.6に 岩綿吸音板と木材の複素比誘電率の周波数分散を示す。Rhim らはコ ンクリートやモルタルの複素比誘電率の周波数分布を $1 \mathrm{GHz} \sim$ $20 \mathrm{GHz}$ に渡って測定しており，同帯域での水の複素比誘電率の実測 值から，周波数の上昇と共に実部は減少し，虚部は上昇すると報告 ${ }^{8)}$ している。さらに千葉らもコンクリートについてモデル化を行い, 同様な結果 ${ }^{9)}$ を示している。

Fig.4〜Fig.6 の結果は, 複素比誘電率の実部・虚部共に大きな周波 数特性を示してはいない。しかし，詳細に検討すれば評価周波数の 両端部を除き，すべての材料について周波数の上昇と共に複素比誘 電率の実部は減少しており, 虚部は繊維強化セメント板について,

Table 1 Description of measured building materials

\begin{tabular}{|c|c|c|c|c|c|}
\hline Name of Material & Type & $\begin{array}{c}\text { Thickness } \\
\text { (mm) }\end{array}$ & $\begin{array}{c}\text { Number of } \\
\text { Samples }\end{array}$ & Symbol & $\begin{array}{l}\text { Density } \\
\left(\mathrm{g} / \mathrm{cm}^{3}\right)\end{array}$ \\
\hline \multirow{4}{*}{$\begin{array}{c}\text { Fiber Reinforced } \\
\text { Cement Board }\end{array}$} & I & 3.9 & 5 & SKC1 & 1.71 \\
\hline & II & 4.2 & 4 & $\mathrm{SKC} 2$ & 1.68 \\
\hline & III & 4.2 & 2 & SKC3 & 1.60 \\
\hline & IV & 6.0 & 3 & SKC4 & 1.11 \\
\hline \multirow{2}{*}{ Plaster Board } & I & 9.3 & 2 & GY1 & 0.72 \\
\hline & II & 12.4 & 4 & GY2 & 0.71 \\
\hline $\begin{array}{c}\text { Sound Absorbing } \\
\text { Board }\end{array}$ & & 15.0 & 1 & RW & 0.39 \\
\hline \multirow{2}{*}{ Wood } & I & 13.3 & 1 & WD1 & 0.28 \\
\hline & II & 8.9 & 1 & WD2 & 0.57 \\
\hline
\end{tabular}

Table 2 Maximum frequency variation of complex relative permittivity for $1.55 \mathrm{GHz}$ to $6.5 \mathrm{GHz}$

\begin{tabular}{|c|c|c|c|c|c|}
\hline \multirow{2}{*}{$\begin{array}{l}\text { Name of } \\
\text { Material }\end{array}$} & \multirow{2}{*}{ Type } & \multicolumn{2}{|c|}{ Maximum Variation (\%) } & \multirow{2}{*}{$\begin{array}{l}\text { Density } \\
\left(\mathrm{g} / \mathrm{cm}^{3}\right)\end{array}$} & \multirow{2}{*}{$\begin{array}{c}\text { Water Content } \\
(\%)\end{array}$} \\
\hline & & $\varepsilon_{r}^{\prime}$ & $\varepsilon_{r}^{\prime \prime}$ & & \\
\hline \multirow{4}{*}{$\begin{array}{c}\text { Fiber } \\
\text { Reinforced } \\
\text { Cement Board }\end{array}$} & I & 4.54 & 6.75 & 1.71 & 6.57 \\
\hline & II & 4.55 & 6.4 & 1.68 & 6.90 \\
\hline & III & 5.55 & 11 & 1.60 & 4.95 \\
\hline & IV & 8.34 & 29.02 & 1.11 & 3.47 \\
\hline \multirow{2}{*}{ Plaster Board } & I & 7.21 & 272 & 0.72 & 12.20 \\
\hline & II & 14.67 & 584 & 0.71 & 12.42 \\
\hline $\begin{array}{l}\text { Sound } \\
\text { Absorbing } \\
\text { Board }\end{array}$ & & 31.70 & 273 & 0.39 & 1.43 \\
\hline \multirow{2}{*}{ Wood } & I & 8.85 & 84.05 & 0.28 & 13.25 \\
\hline & II & 12.72 & 40.13 & 0.57 & 8.93 \\
\hline
\end{tabular}



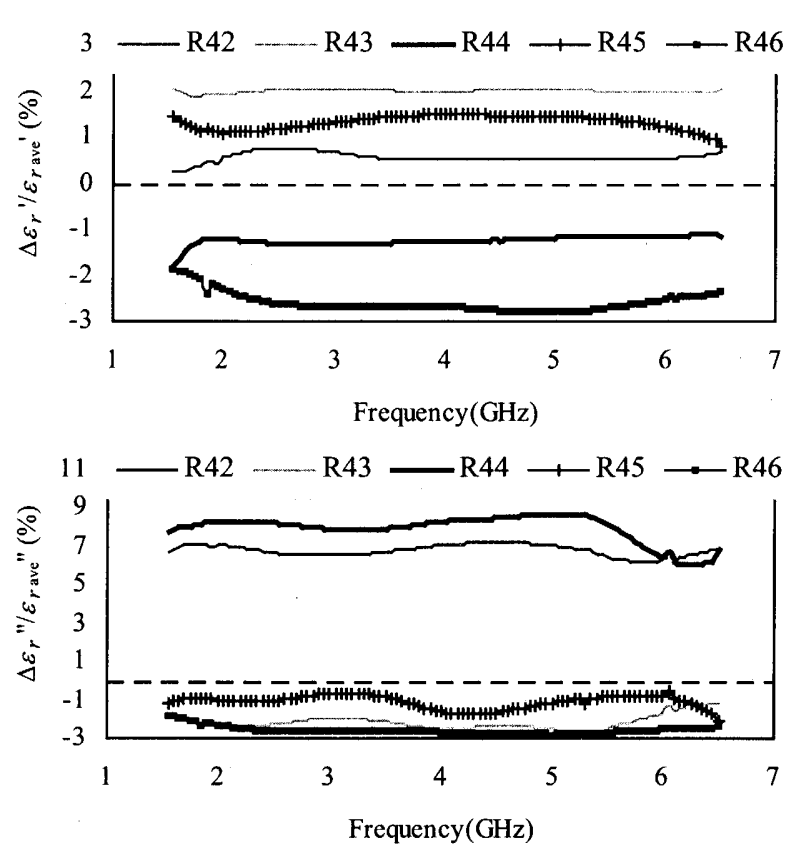

Fig.7 Variation of relative complex relative permittivity in frequency for fiber reinforced cement board Type I

微増の傾向があることがわかる。これは, 先の Rhim らや千葉らの 報告と傾向が一致していることから, 対象とする本周波数帯域にお いても, 複素比誘電率の周波数特性をきちんと考察する必要がある こと, そして本手法による複素比誘電率の算出方法の有効性が確認 できた。

特に Fig.6 に示した材料はその傾向が強く見られたが, これらは 比重が軽く空孔が多いために, 他の材料に比べて水の影響が強く出 ていることが考えられる。さらに, 石膏ボードの複素比誘電率の測 定值は橋本らの自由空間透過法による測定結果 ${ }^{11}$ とよく一致してお り，本測定值の有効性が確認できた。

さらに, Table2 に対象周波数帯域 $1.55 \mathrm{GHz} \sim 6.5 \mathrm{GHz}$ での各材料の 複素比誘電率の最大值と最小值の差を帯域中での平均值の比（周波 数分散）として示す。材料の密度が小さくなるにつれて周波数分散 が大きくなっていることがわかり, 瀻維強化セメント板 I,II では複 素比誘電率の実部で $5 \%$ 程度, 虚部で 6〜10\%程度である。また, こ の表には測定時の重量から絶対乾燥状態（105 $\mathrm{C}$ のーブンで 100 時間設置) での重量をさし引いて求めた含水率も合わせて示してあ る。繊維強化セメント板 I〜III の含水率は 5〜7\%で, 含水率の高い

Table 3 Average and standard deviation of complex relative permittivity for $1.55 \mathrm{GHz}$ to $6.5 \mathrm{GHz}$

\begin{tabular}{|c|c|c|c|c|c|}
\hline Name of Material & \multirow{2}{*}{ Type } & \multicolumn{2}{|c|}{$\varepsilon_{r^{\prime}}$} & \multicolumn{2}{|c|}{$\varepsilon_{r}^{\prime \prime}$} \\
& & Average & $\sigma$ & Average & $\sigma$ \\
\hline \hline Fiber Reinforced & I & 6.20 & 0.12 & 0.91 & 0.07 \\
Cement Board & II & 6.50 & 0.1 & 0.82 & 0.05 \\
& IV & 3.63 & 0.02 & 0.31 & 0.01 \\
\hline Plaster Board & I & 2.37 & 0.04 & 0.01 & 0.002 \\
\hline
\end{tabular}

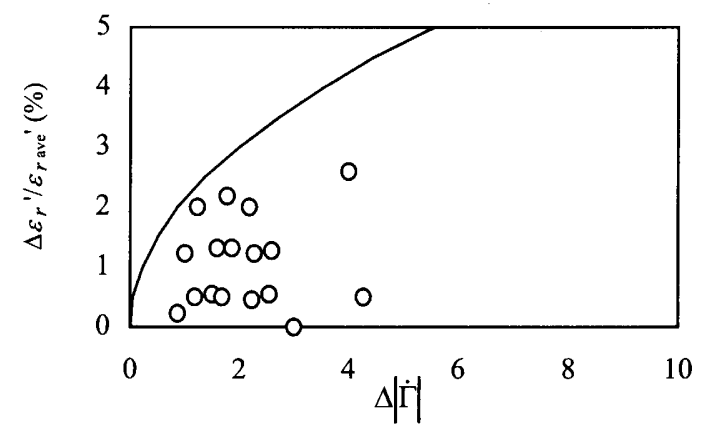

Fig.8 Characteristics of the calculated $\Delta|\dot{\Gamma}|$ to $\Delta \varepsilon_{r}^{\prime} / \varepsilon_{r}$ ave'

石高ボードや木材と比べて周波数分散が小さく，これらの結果は Rhim らの $1 \mathrm{GHz} \sim 20 \mathrm{GHz}$ でのモルタルやコンクリート ${ }^{8)}$ や笠嶋らの $100 \mathrm{MHz} \sim 1 \mathrm{GHz}$ での繊維補強コンクリートでの結果 ${ }^{2)}$ ともよく一致 している。岩綿吸音板については含水率が微小であるが, 周波数分 散が大きい絬果になっており，この点については今後の検討課題で ある。

次に試料閒のばらつきについて検討する。Fig.7 に繊維強化セメン 卜板 Iについて, 各試料（R42〜R46）の複素比誘電率の周波数分布 を各周波数での平均值との差に対する比として示す（求められた複 素比誘電率の平均值 $\varepsilon_{r}$ ave (実部)及び $\varepsilon_{r}$ ave" (虚部) に対して, 各試 料の偏差を $\Delta \varepsilon_{r}^{\prime}$ 及び $\Delta \varepsilon_{r}{ }^{\prime \prime}$ とると $\Delta \varepsilon_{r}{ }^{\prime} / \varepsilon_{r}$ ave'及び $\Delta \varepsilon_{r}{ }^{\prime \prime} / \varepsilon_{r}$ ave")。実 部については $0.5 \%$ 程度, 虚部については $2 \%$ 程度の範囲内での変動 にとどまっており，その幅は周波数によらず変化していない。この ような傾向は試料数の多い繊維強化セメント板 II や石高ボードでも 見られ, 試料間の複素比誘電率の変動を評価する際には, 対象周波 数帯域での平均值を使って検討を行ってよいことがわかる。

そこで試料が 3 枚以上ある繊維強化セメント板 I,II,IV,及び石高ボ ード II について複素比誘電率のばらつきを評価した。Table3 に $1.55 \mathrm{GHz} \sim 6.5 \mathrm{GHz}$ 帯域での複素比誘電率の平均值を標準偏差 (表中 ではのと表している）と共に示す。この表から標準偏差の平均值に 対する比を材料のばらつきであると考えると, 同一バッチでの複素 比誘電率のばらつきは実部で $2 \%$, 虚部で $8 \%$ (石高ボードを除いて) と評価できる。実部に比べて虚部でばらつきが大きいのは, 絶対值 が小さいためで, 特に石高ボードについては複素比誘電率の虚部が 微小であるためにばらつきが大きくなっていると考えられる。

さらに, 試料内のばらつきを評価するために同一試料を 90 度ずつ 回転させ表裏 8 つの状態でオープン測定とショート測定を行い, 1 状態ごとにオープンとショートの 2 つの測定結果から複素比誘電率 を算出した。測定した試料は瀻維強化セメント板 II である。この結 果, 複素比誘電率のばらつきは（標準偏差の平均値に対する比）実 部で $0.7 \%$ ，虚部で $4.3 \%$ であった。

最後に複素比誘電率を算出する際の反復計算によって求められた 式（9）の $\Delta|\dot{\Gamma}|$ の最小值 (収束值) と求められた複素比誘電率の平 均からの偏差の関係を検討する。すなわち反復計算が十分収束しな ければ, 評価された複素比誘電率の精度が低く, 偏差が大きくなる ため, $\Delta|\dot{\Gamma}|$ と複素比誘電率の偏差との関係を導くことによって精 度よい測定のための式(9)の収束值の条件を明らかにできる。

Fig.8 に各試料の式(9)の収束値 $\Delta|\dot{\Gamma}|$ と算出された複素比誘電率 
実部項の平均值からの偏差の平均值に対寸る比（求められた複素比 誘電率の平均値 $\varepsilon_{r}$ ave'に対して, 各試料の偏差を $\Delta \varepsilon_{r}^{\prime}$ とすると $\Delta \varepsilon_{r}^{\prime} / \varepsilon_{r}$ ave'）との関係を示す。図には 3 試料以上測定データがある 繊維強化セメント板 I, II, IV 及び石雷ボードII の結果のみを示し ている。瀻維強化セメント板 I の平均複素比誘電率を $0 \sim \pm 5 \%$ 変化 させ式(9)から計算した $\Delta|\dot{\Gamma}|$ の変化曲線も合わせて示してある。

この図から,すべての測定点が複素比誘電率の偏差を仮定して計 算された曲線よりも偏差が小さく, 収束值 $\Delta|\dot{\Gamma}|$ が 3 程度以下な らば, 算出された複素比誘電率は $2.5 \%$ 程度の偏差で収まることが わかった。このことから, 本手法による複素比誘電率算出の際の収 束値は 3 程度以下が望ましく, その際に算出された複素比誘電率の 偏差は $2.5 \%$ 程度以下であること, 収束值 5 程度に対しては複素比 誘電率の偏差が $5 \%$ 程度以下であることが確認できた。

\section{4.おわりに}

内装用建材の複素比誘電率を, 測定が比較的容易な自由空間反射 損失法による反射係数の振幅のみから算出する方法を提案し，代表 的な内装用建材として石高ボード, 瀻維強化セメント板, 岩綿吸音 板, 木材の 9 種類 23 試料の測定を行い, 複素比誘電率を評価した。 測定試料はあらかじめ恒温養生室 $\left(20^{\circ} \mathrm{C}\right.$, 相対湿度 $\left.60 \%\right)$ に一定期 間養生し, 反射係数測定は $1 \mathrm{GHz} \sim 13.5 \mathrm{GHz}$ の帯域で, 複素比誘電 率の算出は無線 LAN の使用周波数帯域を含む $1.55 \mathrm{GHz} \sim 6.5 \mathrm{GHz}$, $50 \mathrm{MHz}$ ステップで行った。その結果，以下のことがわかった。

（1）代表的な内装用建材の複素比誘電率の周波数分布を求め, 対象 周波数帯域において複素比誘電率の実部は減少し, 虚部は增加 するという傾向があることがわかった。

（2）ただしその増減幅は含水率の多賽によって異なり，含水率が高 い方が帯域中での複素比誘電率の変動幅が大きく, 本条件下で の瀻維強化セメント板の複素比誘電率の変動幅は実部で $5 \%$ 程 度, 虚部で 6〜10\%であった。

(3) これらのことはコンクリートやモルタルなどの材料における 過去の検討と傾向が一致し, 石曹ボードについてはその絶対值 も過去の報告とよい一致が見られた。

(4) 試料のばらつきは同一バッチの瀻維強化セメント板と石亮ボ 一ドについて評価し, 複素比誘電率の実部で $2 \%$, 虚部で $8 \%$ 程度であった。

(5) 同一試料内でのばらつきも㵶維強化セメント板について評価 した結果, 複素比誘電率の実部で $0.7 \%$, 虚部で $4.3 \%$ であった。

(6) 複素比誘電率算出の反復計算の収束値と各試料の平均値から の偏差との関係の検討から, 収束値 3 以下の場合は偏差が 2. $5 \%$ 程度以下, 収束值 5 以下の場合には偏差が $5 \%$ 程度以下であ ることが確認できた。

本論文では同一バッチの試料を扱って内装用建材の複素比誘電率 の評価を行ったが，今後はバッチの異なるものも含めてより多くの 試料を測定することによって，より確度の高い評価を行う必要があ る。
参考文献

1) 橋本修：マイクロ波・ミリ波帯におおる測定技術, リアライズ社, 1998

2) 笠嶋善憲, 小林三亀雄, 中川裕章：建物によるテレビ電波反射障害防 止用電波透過型カーテンウォール，信学技報，EMCJ94-96，pp.75-82,1995

3) 國分誠, 長田耕治 : 骨材種類の違いによる誘電吸収型電波吸収体の含水 率特性, 日本建築学会大会学術講演梗概集 D-1, pp.1019-1020, 1996

4) 宮崎弘志, 佐川祐一郎, 寺西佳子: テレビ電波障害防止法に関する研究, 日本建築学会大会学術講演梗概集 D-1, pp.1021-1023，1996

5) 平池太郎, 三枝健二, 長谷部望 : 球面空間定在波を用いた材料の反射係 数測定法, 電子情報通信学会論文誌 B,Vol.J85-B,No.4,pp.547-554,2002

6) 千葉元, 宮崎保光：建設施工現場における $\mathrm{RC}$ スラブの電波反射・透 過特性, 電子情報通信学会論文誌 B-I,Vol.J80-B-I,No.1,pp.110-120,1997

7) Bois, K. J., Benally, A. D. and Zoughi, R.: "Microwave Near-Field Reflection Property Analysis of Concrete for Matrial Content Determination", IEEE Trans. Instrum. Meas., Vol. 49, No.1, pp.49-55, 2000

8) Rhim, H. C., and Büyuközturk, O. :Electromagnetic Properties of Concrete at Microwave Frequency Range, ACI Material Journal,Vol.95,pp.262-271, 1998

9) Zoughi, R., Gray, S. D., and Nowak, P. S. :Microwave Nondestructive Estimation of Cement Paste Compressive Strength, ACI Material Journal, Vol. 92, pp.64-70, 1995

10）木村健一：無線通信制御に関する検討 その 1, 日本建築学会大会学術 講演梗概集 D-1，pp.1131-1133，2002

11）橋本修, 佐藤篤樹, 花澤正理宏, 谷健祐, 遠藤哲夫 : C 帯における自由 空間透過法による複素比誘電率測定に関する研究, 電子情報通信学会論 文誌 B,Vol.J86-B,No.7,pp.1089-1094,2003

12) Ghodgaonkar, D. K., Varadan, V. V. and Varadan, V. K. : A Free Space Method for Measurement of Dielectric Constants and Loss Tangents at Microwave Frequency, IEEE Trans. Instrum. Meas., Vol. 38, No3, pp.789-793, 1989

13) Ma, Z. and S. Okamura: Permittivity Determination Using Amplitudes of Transmission and Reflection Coefficients at Microwave Frequency, IEEE Trans. Microwave Theory Tech., Vol. 47, No.5, pp.546-550, 1999

14) 木村健一，久保知也，白水廣一，橋本修：自由空間法による複素比誘電 率測定における試料寸法に関する実験的検討, 電子情報通信学会論文誌 B, Vol. J85-B, No.11, pp.1964-1967, 2002

15) 橋本修, 東壽志, 織壁健太郎, 石坂宏幸： $60 \mathrm{GHz}$ 体におけるレーダー ドーム用材料の複素比誘電率測定, 電子情報通信学会論文誌 B-II,Vol.J80-B-II,No.10,pp.906-911,1997

16) Harris, F. J. : On the use of Windows for Harmonic Analysis with the Discrete Fourier Transform, Proceedings of the IEEE, Vol 66, No.1, pp.51-83, 1978

17) 大塚健二郎，橋本修，石田貴久： $94 \mathrm{GHz}$ 帯における自由空間法を用いた 低損失材料の複素比誘電率測定, 電子情報通信学会論文誌 B Vol.J82-B, No.8, pp.1602-1604, 1999 
Abstract

It is very important to estimate electrical constant including complex relative permittivity accurately for the efficient discussion of electromagnetic compatibility inside and/or around building. Various methods have been reported for the determination of the complex relative permittivity of non-magnetic materials, such as Resonator Method, Waveguide Method and Free Space Method. However, few works conduct for building materials, especially interior building materials.

So, we estimate the complex relative permittivity for interior building materials by using four measurements of the magnitude of the reflection coefficient from the Free Space Measurement System and iteration calculation. Fig.1 shows the outline of the measurement system. Before the estimation of the complex relative permittivity, we confirm the effectiveness of the measurement system by using acrylic plate (Fig.2).

Four measurements are follows, backed by a metal plate from front side (front-short), samples only from front side (front-open), samples backed by a metal plate from back side (back-short), and samples only from back side (back-open).

The calculation starts to put above four measurements data and the calculated reflection coefficient by initial guess complex relative permittivity into equation (9). The calculated reflection coefficient can be conducted by using equation (1) to (8) for open and short measurement. The iteration calculation perform to minimize the value of $\Delta|\dot{\Gamma}|$ under the certain value of the standard deviation for the complex relative permittivity, and the target complex relative permittivity should be obtained when the value of $\Delta|\dot{\Gamma}|$ achieve to minimum.

The measurement of the reflection coefficient performs for $1 \mathrm{GHz}$ to $13.5 \mathrm{GHz}, 501$ points, $25 \mathrm{MHz}$ steps, and the iteration calculation for 1.55 $\mathrm{GHz}$ to $6.5 \mathrm{GHz}, 100$ points, $50 \mathrm{MHz}$ steps in this work. Table 1 shows samples for the estimation ( 9 kinds of materials and 23 samples). These samples put into standard humidifier (temperature is $20{ }^{\circ} \mathrm{C}$ and humidity is $60 \%$ ) in certain days to make samples homogeneous with respect to water content

Fig.3, Fig.4 and Fig.5 show the frequency distribution of the complex relative permittivity for Fiber Reinforced Cement Boards, Plaster Boards, Sound Absorbing Boards, and Woods. The real part of the complex relative permittivity decreases for the higher frequency for all samples, and the imaginary part of the complex relative permittivity for Fiber Reinforced Cement Boards increases for the higher frequency. These results have good agreement to the work done by $\mathrm{Rhim}^{8}$ ) for the measurement of mortal and concrete from $1 \mathrm{GHz}$ to $20 \mathrm{GHz}$ and Chiba' for the simulation of the concrete. And the estimated complex relative permittivity for Plaster Boards are agree to the value presented by Hashimoto ${ }^{11)}$ by using Free Space Transmission Method.

Table 2 shows the maximum frequency variation of the complex relative permittivity (the ratio to the average value) for $1.55 \mathrm{GHz}$ to $6.5 \mathrm{GHz}$. The variation increases for the lower density. The value of the frequency variation of Fiber Reinforced Cement Board Type I and II is about $5 \%$ for the real part of the complex relative permittivity and $6-10 \%$ for the imaginary part of the complex relative permittivity.

Fig.6 shows the variation of the complex relative permittivity in the frequency for Fiber Reinforced Cement Board Type I (sample name are R42 to R46). The variation of the real part of the complex relative permittivity is within $0.5 \%$ and that of the imaginary part is within $2 \%$ for all frequency range. Same kinds of results are presented from the other samples. So these results conclude that the estimation for the variation of the samples can be performed by using an average value for the frequency.

Table 3 shows the average and the standard deviation of the complex relative permittivity of Fiber Reinforced Cement Board Type I, II, IV and Plaster Board Type I for $1.55 \mathrm{GHz}$ to $6.5 \mathrm{GHz}$. From the table, the variation of the samples are $2 \%$ for the real part of the complex relative permittivity and $8 \%$ for the imaginary part of the complex relative permittivity excluding Plaster Board Type I..

The variation of the complex relative permittivity within the one sample by deferent setting for the measurement is also conducted by rounding the sample by 90 degrees with open and short measurement. The results of the variation are $0.7 \%$ for the real part of the complex relative permittivity and $4.3 \%$ for the imaginary part of the complex relative permittivity.

Finally, the relationship between $\Delta \mid \dot{\Gamma}$ and the deviation of the complex relative permittivity is investigated for proper calculations. Fig.7 shows the characteristics of the calculated $\Delta|\Gamma|$ and $\Delta \varepsilon_{r}^{\prime} / \varepsilon_{r}$ ave' , for Fiber Reinforced Cement Board Type I,II,IV and Plaster Board Type I with the curve calculated by varying the average complex relative permittivity of Fiber Reinforced Cement Board Type I in the range of 0 to $\pm 5 \%$. All points are below the calculated curve, thus, for the proper calculation of the complex relative permittivity described here, the value of $\Delta|\dot{\Gamma}|$ could be below 3, expecting $2.5 \%$ as the variation of the calculated complex relative permittivity, and 5 for the value of $\Delta|\dot{\Gamma}|$ expects $5 \%$ for the variation of the complex relative permittivity. 